\title{
Sepsis Neonatal: Epidemiology, Etiology and Risk Factors
}

\author{
Silva NBS ${ }^{1}$, Menezes RP ${ }^{2}$, Brito $\mathrm{MO}^{3}$, Alves PGV ${ }^{2}$, Pedroso $\mathrm{RS}^{3}$ and Röder DVDB ${ }^{1 *}$ \\ ${ }^{1}$ Federal University of Uberlândia, Institute of Biomedical Sciences, Brazil \\ ${ }^{2}$ Federal University of Uberlândia, College of Medicine, Brazil \\ ${ }^{3}$ Federal University of Uberlândia, Technical School of Health, Brazil
}

Submission: June 23, 2017; Published: July 20, 2017

*Corresponding author: Denise Von Dolinger de Brito Röder (Röder DVDB), Av. Amazonas s/no, Bloco 4K, Sala 111, Campus Umuarama, Uberlândia, MG, Postal Code 38400-902, Brazil, Email: denise.roder@ufu.br

\begin{abstract}
Neonatal sepsis, a clinical disorder developed by bacterial blood stream infections in neonates, is one of the serious global public health problems that must be addressed. More than one million of the estimated global newborn deaths per year are occurred due to severe infections. Neonatal sepsis is divided into early-onset sepsis and late-onset sepsis of the disease. The clinical complications of neonatal sepsis may be associated with broncho pulmonary dysplasia, ductus arteriosus and necrotizing enterocolitis. The clinical diagnosis and treatment of neonatal sepsis is highly complicated. Microbiological surveillance and assessment of antimicrobial resistance is a key component in decreasing the rate of neonatal sepsis and the associated mortality. There are a number of important gaps in our knowledge and a lack of studies looking at simple and sustainable interventions to reduce the burden of neonatal sepsis. The lack of culture driven antimicrobial therapy and limited consistent infection control practices are likely responsible for the high incidence rates of neonatal sepsis and mortality.
\end{abstract}

Keywords: Sepsis; Critically neonates; Risk factors; Surveillance

\section{Introduction}

Healthcare-associated infections are frequent and critical complications associated with hospitalization of neonates, especially very low birth weight neonates, in neonatal intensive care units (NICU) [1]. Neonatal infections currently cause about 1.6 million deaths per year in developing countries. Sepsis and meningitis are responsible for most of these deaths [2]. Neonatal infections annually claim lives of 1.4 million neonates worldwide. Early-onset neonatal sepsis occurs within $72 \mathrm{~h}$ of birth, while late-onset neonatal sepsis occurs after the first $72 \mathrm{~h}$ of life and both are major causes of infant mortality [3].

The clinical signs and symptoms associated with neonatal infections are nonspecific because of an over lapped disease out comes with infections occurred by other diseases, and hence prior detection and treatment becomes crucial for the better neonatal outcomes. Over diagnosis of neonatal infections results in anill-suited and inappropriate usage of antibiotics, causing risks of antibiotic resistance [4]. Additionally, sepsis is a challenging complication that affects other morbidities, length of hospitalization, cost of care, and mortality rates.

Improvements in outcome and successful treatment depend largely on early initiation of appropriate antibiotic therapy.
The aetiology of neonatal sepsis in developing countries differs from that in developed countries in the pattern of etiological bacteria and their antibiotic susceptibility [5]. Bacteria, such as Streptococcus, L. monocytogenes, E. faecalis, E. faecium, group D Streptococci, $\alpha$-hemolytic Streptococci and Staphylococci, S.pneumoniae, $\mathrm{H}$. influenza type $\mathrm{B}$, are recognized as the principal cause of early neonatal sepsis. Less commonly, $\mathrm{N}$. meningitides and $\mathrm{N}$. gonorrhoeae have been also reported as a cause of neonatal septicemia and Gram-negative enteric organisms predominantly E. coli, Klebsiella species are included [6]. On the other hand, late-onset sepsis is predominantly caused by Staphylococci species and Escherichia coli. Sometimes Entero bactercloacae or Citrobacter freundii from blood may be due to contaminated feedings.

Contaminated respiratory equipment is suspected in outbreaks of hospital-acquired Pseudomonas aeruginosa pneumonia or sepsis [7]. A neonate may be at risk of infection through one or many intrinsic and extrinsic factors, such as gestational age and presence of a single or multiple invasive devices. In developed and developing countries, most nosocomial infections in NICUs are related to a longer duration of hospitalization, low birth weight and gestational age, respiratory 
diseases, invasive interventions, and medical treatments [8]. S. epidermidis emerged in the last several years as a pathogen in a growing number of serious nosocomial infections in neonatal intensive care units, particularly as bloodstream infection, and is a common complication of the prolonged hospitalization of preterm newborns [9].

Candidiasis is one of the leading causes of blood stream infections in neonatal intensive care units (NICUs) and associated with high morbidity and mortality. It has been estimated that $2.4-9.0 \%$ of mortality and $25.0 \%$ of morbidity in the NICU setting may be attributable to Candida infections [10]. Candida albicans and Candida parapsilosis are the leading causes of invasive fungal disease in premature infants, with the intestinal tract being an important site for Candida invasion. Life-threatening gastrointestinal tract diseases that occur in premature infants such as necrotizing enterocolitis and spontaneous intestinal perforation are highly associated with concurrent diagnoses of invasive candidiasis. C. albicans and C. parapsilosis, along with other fungi, are prevalent commensals of the intestinal tract of infants, with high amounts of Candida colonization within the intestine being correlated with an increased risk for invasive disease [11].

Finally, microbiological surveillance and assessment of antimicrobial resistance is a key component in decreasing the rate of neonatal sepsis and the associated mortality. There are a number of important gaps in our knowledge and a lack of studies looking at simple and sustainable interventions to reduce the burden of neonatal sepsis. The lack of cultured driven antimicrobial therapy and limited consistent infection control practices are likely responsible for the high incidence rates of neonatal sepsis and mortality [12].

\section{References}

1. Buetti N, Atkinson A, Kottanattu L, Bielicki J, Marschall J, et al. (2017) Patterns and trends of pediatric blood stream infections: a 7-year surveillancestudy. Eur J Clin Microbiol Infect Dis 36(3): 537-544.
2. Dramowski A, Aucamp M, Bekker A, Mehtar S (2017) Infectious disease exposures and outbreaks at a South African neonatal unit with review of neonatal outbreakepidemiology in Africa. Int J Infect Dis 57: 79-85.

3. Nouetchognou JS, Ateudjieu J, Jemea B, Mesumbe EN, Mbanya D (2016) Surveillance of nosocomial infections in the Yaounde University Teaching Hospital. Cameroon Res Notes 9(1): 505.

4. Chauhan N, Tiwari S, Jain U (2017) Potential biomarkers for effectivescreeningof neonatal sepsisinfections: Anoverview. Microb Pathog 107: 234-242.

5. IzetaSoftić, Husref Tahirović, Vincenzo Di Ciommo, Cinzia Auriti (2017) Bacterialsepsis in neonates: Single centre study in a Neonatal intensivecareunit in Bosniaand Herzegovina. Acta Medica Academica 46(1): 7-15.

6. Mukhopadhyay S, Puopolo KM (2017) Clinical and Microbiologic Characteristics of Earlyonset epsis Among Very Low Birth Weight Infants. Pediatr Infect Dis J 36: 477-481.

7. Lona Reyes JC, Verdugo Robles MÁ, Pérez Ramírez RO, Pérez Molina JJ, Ascencio Esparza EP, et al. (2015) Etiology and antimicrobial resistance patterns in early and late neonatal sepsis in a Neonatal Intensive Care Unit. Arch Argent Pediatr 113(4): 317-323.

8. Ertugrul S, Aktar F, Yolbas I, Yilmaz A, Elbey B, et al. (2016) Risk Factors for Health Care-Associated BloodstreamInfections in a Neonatal IntensiveCare Unit. Iran J Pediatr 26(5): e5213.

9. Fill Malfertheiner S, Wendt S, Layer F, Weigl M, Seelbach-Göbel B, et al. (2017) Prevalence, clonality, and pathogenicity of Staphylococcus epidermidis isolates in newborn feces. Eur J Clin Micro biol Infect Dis 30: 1-10.

10. Chen J, Jiang Y, Wei B, Ding Y, Xu S, et al. (2016) Epidemiologyofandriskfactors for neonatal candidemiaat a tertiarycare hospital in western China. BMC Infect Dis 16(1): 700.

11. Gonia S, Archambault L, Shevik M, Altendahl M, Fellows E, et al. (2017) Candida parapsilosis protects premature intestinal epitelial cellsfrominavsion and damage by Candida albicans. Front Pediatr 5: 54.

12. Chen YC, Lin CF, Rehn YF, Chen JC, Chen PY, et al. (2017) Reduced nosocomial infection rate in a neonatal intensive care unitduring a 4-year surveillance period. J Chin Med Assoc 80(7): S1726-S4901.

\section{Your next submission with Juniper Publishers} will reach you the below assets

- Quality Editorial service

- Swift Peer Review

- Reprints availability

- E-prints Service

- Manuscript Podcast for convenient understanding

- Global attainment for your research

- Manuscript accessibility in different formats

( Pdf, E-pub, Full Text, Audio)

- Unceasing customer service

Track the below URL for one-step submission https://juniperpublishers.com/online-submission.php 